TAPROBANICA, ISSN 1800-427X. November, 2021. Vol. 10, No. 02: pp. 123, pl. 26.

(C) Research Center for Climate Change and Department of Biology, Faculty of Mathematics \& Natural Sciences, University of Indonesia, Depok 16424, INDONESIA.

http://www.taprobanica.org

https://doi.org/10.47605/tapro.v10i2.259

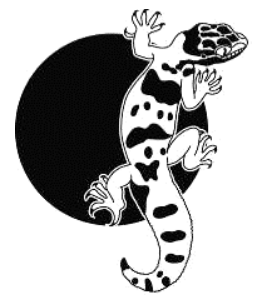

\section{Slate-red tarantula (Poecilotheria rufilata) in the Western Ghats, India}

The Slate-red tree spider (or tarantula), Poecilotheria rufilata Pocock, 1899 is an extremely rare, endemic, little known tarantula described based on a female specimen from Thiruvananthapuram Kerala, India. This arboreal tree spider is mostly found in dead red pine, jack fruit, and white pine trees and recorded from Agasthyamala Biosphere Reserve, Peppara Dam, Kallar, and Ponmudi areas between 900-1200 m elevations (Charpentier 1996) in Kerala (Fig. 1). It is morphologically similar to $P$. ornata Pocock, 1899, which is distributed in Sri Lanka.

A specimen of $P$. rufilata (Fig. 2) was found on a teak tree (7-8 metres above the ground) at Agasthyamala Biological Park, Kerala ( $8^{\circ} 39^{\prime} \mathrm{N}$ $77^{\circ} 13$ 'E; alt. $700 \mathrm{~m}$ a.s.1.) on 15 June 2013. Again, on 8 October 2013, two mature females were captured from Achankovil, Kerala (96'17"N, 775'26"E; alt. $700 \mathrm{~m}$ a.s.1.). All the specimens were captured from tree burrows, preserved in $70 \%$ alcohol, and deposited at the Biodiversity Museum, Deva Matha College, Kuravilangad (Cat. Nos. DMCK 132-134). A Canon EOS 600D Digital Camera was used to capture images of live spiders. Microphotographs were taken using Canon Utility Software with a Canon EOS 600D digital camera connected to a Labomed CZM6 stereozoom microscope. The spermathecae was dissected and cleared in potassium hydroxide solution.

The species is identified by a greyish red dorsum and a glossy black sternum; legs coxae and trochanters velvety black, palp's femur shiny black; patella and tibia yellowish grey, covered with long red bristles; femora and tibia of the first and second legs black with metallic reflections underneath, but are ornamented with a broad yellow basal patch at the front; patellae yellowish brown; third and fourth legs yellowish brown, covered in long greyish or reddish bristles; maxillae with five tubercles resembling pegs on the inner side; chelicera with twelve protruding teeth; palpal spine carinate; abdomen with a black ventrum and a cone-shaped spermatheca with a blunt apex and a wider base.

Although the current record extends the range of this species $50 \mathrm{~km}$ towards the north, it is still found only in southern Kerala.

\section{Acknowledgements}

I thank the principal of Deva Matha College for providing facilities and Kerala Forest Department for granting permission (WL10-75 22946/2013). The financial support was provided by SERB, India (CRG/2018/004708).

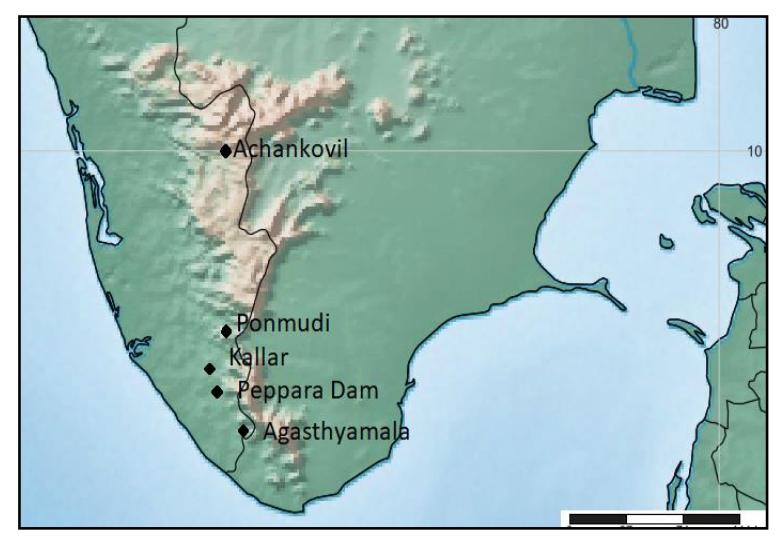

Figure 1. The distribution of Poecilotheria rufilata in the Western Ghats, India

\section{Literature cited}

Pocock, R.I. (1899). Diagnoses of some new Indian Arachnida. Journal of the Bombay Natural History Society, 12(4): 744-753.

Charpentier, P. (1996). The illustrated redescription of Poecilotheria rufilata Pocock 1899. Exothermae Magazine: 14-24.

Submitted: 9 May 2021, Accepted: 7 Nov. 2021 Section Editor: Zeeshan A. Mirza

K. Sunil Jose

Arachnology Lab, Department of Zoology, Deva Matha College, Kuravilangad, Kerala 686633, India E-mail: sunil.jose@devamatha.ac.in 


\section{Plate 26}
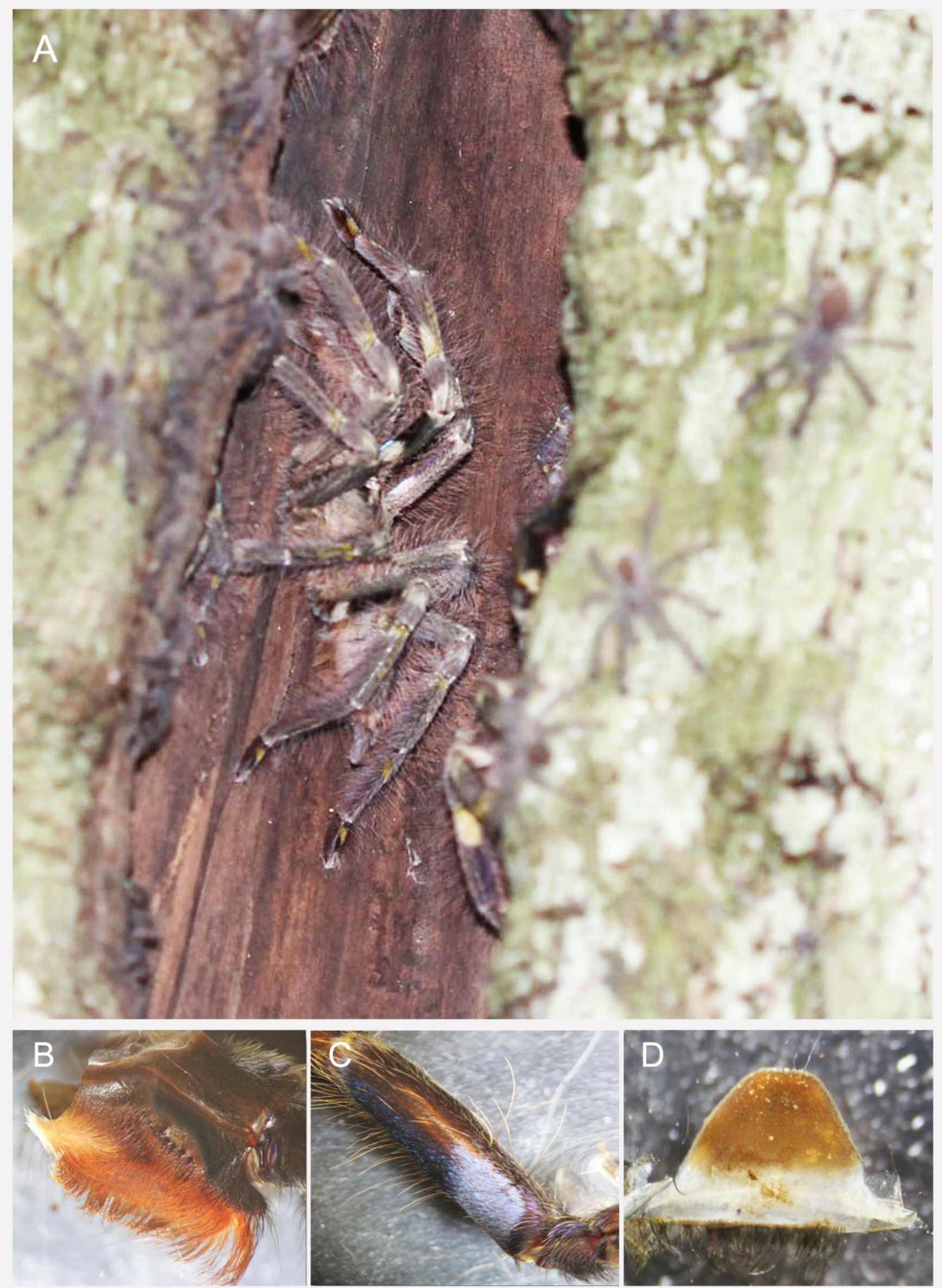

Figure 2. Poecilotheria rufilata: (A) a female in the retreat; (B) maxillae showing stridulating organ; (C) femur of leg I; (D) spermatheca (not to scale). 